\title{
Dialogue for Development: An Exploration of Relations between Oil and Gas Companies, Communities, and the State
}

\author{
FLORIAN STAMMLER AND EMMA WILSON
}

\begin{abstract}
This introduction provides an overview of academic research and current practice relating to stakeholder dialogue around oil and gas development in the Russian North, Siberia and the Russian Far East. We discuss the two main strands of analysis in this special issue: (a) regulation and impact assessment; and (b) relationshipbuilding in practice, with a particular focus on indigenous communities. We argue that an effective regulatory framework, meaningful dialogue, and imaginative organization of stakeholder relations are required to minimize negative impacts and maximize benefits from oil and gas projects. Self-interest, mistrust, and a lack of collective agency frequently lead to ineffective planning and heightened tensions in relations. We identify lessons to be learned from partnerships and initiatives already established in Sakhalin and Western Siberia, despite the lack of a stable legal framework to govern relations. This issue focuses on the academic-practitioner interface, emphasizing the importance of practical application of academic research and the value of non-academic contributions to academic debates.
\end{abstract}

Keywords: Russian oil and gas; Western Siberia; Sakhalin; indigenous peoples; impact assessment; anthropological (ethnological) expert review; etnologicheskaia ekspertiza; collective agency

\section{Introduction}

$\mathrm{O}$ il and gas supplies in Russia and the former Soviet Union are gaining increasing strategic significance in the light of current geopolitical developments, including the expansion of Asian economies and 
instability in oil- and gas-supplying regions of the Middle East and Western Africa. As oil and gas developments expand into ever more sensitive northern regions of Russia, local communities are facing new anxieties about the potential impacts on their livelihoods, as well as issues of how to engage effectively with the oil companies to ensure that oil and gas development provides sustainable local benefits. New dynamics result from the increasing involvement of Western companies in areas where state companies have previously dominated.

This special issue is one of the outputs of the ESRC-sponsored seminar series "Trans-sectoral Partnerships, Sustainability Research and the Oil and Gas Industry in Russia," which covered a range of subjects, from corporate governance, to stakeholder analysis, to community relations and ethnographic research. ${ }^{1}$ The seminar series was designed to address the need for a forum to promote dialogue between diverse interest groups from government, industry, academia, and civil society, and to encourage more debate between Russian and Western voices. This issue aims to do the same by including articles from both academic and non-academic authors, and from those who work at the academic-practitioner interface. Of particular significance to the editors is the emphasis on contributions from Russian authors, including residents of the areas under discussion. The diversity of responses to the issues raised is illustrated by contributions from four major Russian oil and gas regions: Sakhalin Island in the Russian Far East; the Baikal area of southeastern Siberia; and the Khanti-Mansiisk and YamaloNenets autonomous regions in northwest Siberia.

Russia has proven oil reserves of at least 60 billion barrels ( 8 billion tons) or about 6 percent of the world's total. Most of these reserves are in Western Siberia. Russia is the world's second largest oil producer (12 percent of world 2004 production) after Saudi Arabia (13 percent) (Energy Information Administration [EIA] 2006; Neelov 2005). The country is also the world's number one natural gas exporter, counting for around one-quarter of the world's production with reserves of 1,700 trillion cubic feet (48 trillion cubic meters), more than 90 percent of which comes from Western Siberia (EIA 2006; Neelov 2005). Russia's economic recovery after the crisis period of the 1990s is largely due to increased oil and gas exports. In the 1990s the first production sharing agreements (PSAs) were signed in Russia, allowing Western multinationals to take part in oil and gas projects in the country. The first of these were the Sakhalin-1 and Sakhalin-2 projects (see below), and further PSAs have been set up for projects in Western Siberia and European Northern Russia. ${ }^{2}$ 
The Khanti-Mansiisk Autonomous Okrug (Region) or KMAO and the Yamalo-Nenets Autonomous Okrug or YNAO in northwest Siberia are Russia's main oil- and gas-producing regions. ${ }^{3}$ Both of them fuelled the Soviet economy, and are now the biggest net contributors to the Russian federal budget. Of all Russian administrative entities, only Moscow is considered to be richer according to official statistics (KMAO Department for Information 2005). Oil extraction started in the KMAO in the late 1960s on the giant Western Siberian oil deposit of Samotlor near Nizhnevartovsk, and in the YNAO on the then-biggest gas deposit in the world, Medvezhe, near Novyi Urengoi. Today 57.7 percent of Russian oil (7.2 percent of global production) is extracted in the KMAO, while 92 percent of Russian gas comes from the YNAO (KMAO Department for Information 2005; Neelov 2005). Particularly important was the "internationalization" of Tiumen' Oil Company (TNK)—the third-largest oil producer in the KMAO in 2005-through its merger with British Petroleum (BP). TNK is also expanding into Krasnoiarskii Krai. Several multinational companies such as Norsk Hydro and Statoil are bidding for participation in the new Gazprom-operated Shtokman liquefied natural gas (LNG) project that will provide gas to markets in Europe as well as possibly via marine transportation to North America. The direct German involvement in Gazprom and Russian gas production is currently a unique phenomenon. ${ }^{4}$ The German energy provider E.ON Ruhrgas, with 6.4 percent of Gazprom shares, and BASF have long-standing partnerships and together have a 49 percent share in a joint venture with Gazprom for the contested 1,200-km North European Gas Pipeline linking Russia and Germany under the Baltic Sea. ${ }^{5}$ Increasingly Western and multinational companies are seeking to become more active in the KMAO and YNAO. Below we discuss the implications of these developments for local communities in Western Siberia. The KMAO and YNAO are known for the comparatively wellpreserved indigenous ways of life of the Khanty, Mansi, and Nenets fishermen, reindeer herders and hunters, many of whom are still nomadic or semi-nomadic.

In the Russian Far East and Eastern Siberia the oil and gas industry is expanding rapidly. Russia is developing new Asian alliances (with China, Japan, Korea, and India), and Siberian and Russian Far Eastern oil and gas resources are playing a central role, with construction of major oil and gas pipelines: the Eastern Siberia-Pacific Ocean Pipeline and the Sakhalin-1 and -2 project pipelines (see below). Lack of pipeline infrastructure has to date been a factor impeding the expansion of Russia's petroleum exports to eastern markets-currently 90 percent goes 
to European markets. Transneft's $\$ 15$ billion (US) Eastern Siberia-Pacific Ocean Pipeline will extend 4,200 km from southeastern Siberia to the Sea of Japan - over three times the length of the Trans-Alaska Pipelineand will transport 80 million tons of crude oil per year from the fields of the KMAO, Tomskaia Oblast', and Eastern Siberia (Irkutskaia Oblast, Evenkiia, Krasnoiarskii Krai, and the Sakha Republic). ${ }^{6}$ The Baikal area is home to many indigenous and non-indigenous groups, such as Buriaty, Mongolians, Orocheny, Russians, and many others. In this issue, Fondahl and Sirina focus on the concerns of the 700 local Evenki about the potential impact of the pipeline construction on their lives and livelihoods. This group of Evenki suffered similar disruption when the Baikal-Amur Mainline (BAM) railway was constructed in the 1970s.

The oil and gas industry is nothing new to Sakhalin Island in the Russian Far East. Onshore oil production began in the north of Sakhalin as early as the 1920s, with the involvement of the Japanese. ${ }^{7}$ The Sakhalin oil company Rosneft'-Sakhalinmorneftegas is one of the oldest Russian oil companies and is the largest oil and gas production enterprise in the Russian Far East (see Mitrofankin in this issue). ${ }^{8}$ Sakhalin's northern districts depend heavily on tax payments from the onshore oil and gas industry. Sakhalin's offshore reserves are currently estimated at around 14 billion barrels of oil (1.87 billion tons) and 96 trillion cubic feet of gas (2.7 trillion cubic meters) (Brooke 2005). These are currently being developed by major players such as Shell, ExxonMobil, Rosneft, and BP, and are aimed at oil and gas markets in Asia and the Pacific Rim (see Bradshaw 2003b as well as the articles of Mitrofankin and Roon in this issue). The two major projects to date are Sakhalin-1 (Exxon Neftegaz Ltd.), which produced its first oil in 2005, and Sakhalin-2 (Sakhalin Energy Investment Company Ltd.), which started production in 1999. ${ }^{9}$ The Sakhalin-2 Project pipelines will stretch $800 \mathrm{~km}$ from the northeast of Sakhalin to the south for export, while the Sakhalin-1 Project pipelines cut across the island from east to west, to mainland Khabarovskii Krai. Sakhalin's indigenous Nivkhi, Uil'ta (Oroki), Evenki, and Nanaitsy make up just 0.3 percent of the overall island population, but concentrated populations (mostly Nivkhi and a small group of reindeer-herding Uil'ta) live in the north where they make up around 7 percent of the population. Some still practice traditional livelihood activities including reindeer herding and fishing in areas impacted by the multinational projects (see Kwon 1997; Roon 1996, 1999; Wilson 2002a, 2003).

Given the dependence of the Russian and global economies on these resources, and the increasing involvement of international players, the 


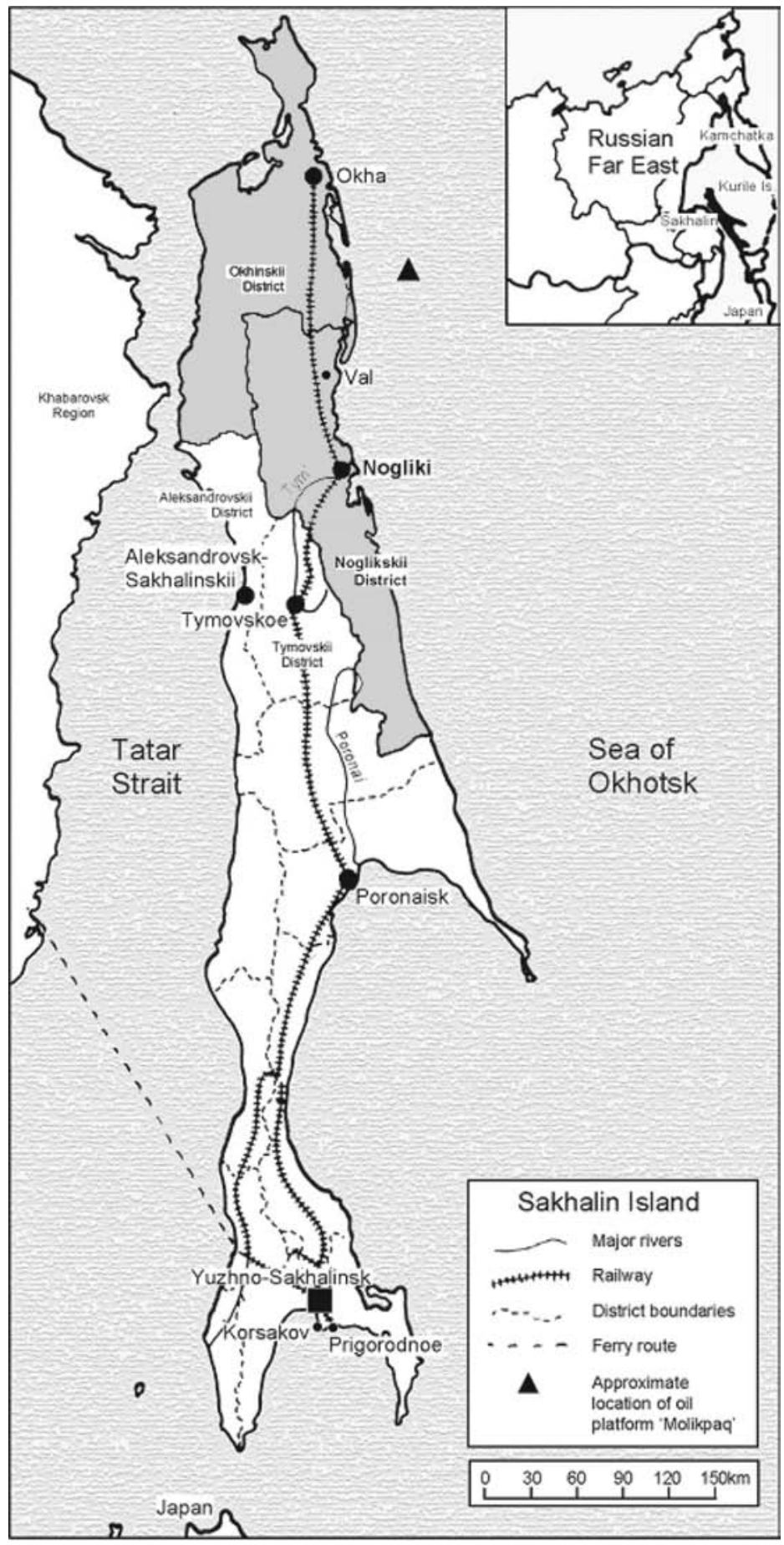


Russian North, Siberia, and the Russian Far East are attracting increasing international attention. Besides the economic importance, growing attention is being paid to the ecological, as well as the social impacts of these developments. For example, a report on the impact of oil and gas development is due to be presented in November 2006 as part of the Arctic Council's Arctic Monitoring and Assessment Program (AMAP). ${ }^{10}$ Other examples include the campaigns around Sakhalin's multinational offshore oil and gas projects and the Eastern Siberia-Pacific Ocean Pipeline.

The vast size and increasing importance of the oil and gas industry in Russia do not guarantee the social and economic security of Russia's oil-producing regions. Large-scale oil and gas developments often result in net negative outcomes, including social disharmony and environmental impacts. Initial economic growth is often unsustainable, and revenues are not necessarily invested in a way to promote long-term sustainable development. The regularity of such development outcomes throughout the world has led to a set of theoretical assumptions about the "resource curse," which makes development "unsustainable" and is especially prevalent in regions with high dependency on mineral resources (Auty 1993; Hausmann and Rigobon 2003; Karl 1997; Najman et al. 2005; Tsalik 2002). Karl (1997) shows in particular how politically weak states with rich oil resources such as Venezuela, Iran, Algeria, and Indonesia are ill-prepared to accommodate large incomes from oil extraction and transfer them into long-term sustainable benefits for their populations. Their response is centralization and bureaucratization. We argue that even though Russia also centralizes its political structure, it is not as politically weak as the states in Karl's analysis. Putin's Russia is even regaining some of the global control and self-confidence that it had lost after the collapse of the Soviet Union.

This special issue of Sibirica addresses one crucial factor influencing the sustainability of oil- and gas-related development-the relations between local communities, the government, and industrial developers. The effectiveness of dialogue between local people, companies and local and regional authorities is influenced by regulatory and economic factors; corporate public engagement policies and the nature of "agreements" between communities and companies; personal characteristics such as trust, self-interest, and negotiating skills; and the "collective agency" of stakeholder groups, a factor that we explain below. We also observe a lack of in-depth analysis of real social and environmental issues on the part of practitioners in this sphere of activity, and suggest that they would benefit from improved dialogue not only with the communities themselves, but also with academic researchers and others 
who have spent long periods living and working in local communities. In particular, this issue focuses on indigenous communities-a focus that we explain below, acknowledging the need not to ignore the claims of long-term non-indigenous residents in these areas and to show them equal attention and concern.

\section{Theoretical Framework}

Analysis of the relations between local communities and the oil and gas industry has broad relevance to theoretical understandings of social organization, local self-governance, and political economy. In any region where subsurface resources are extracted, local and indigenous communities experience significant, often rapid, social and economic change. Thus, insights from the study of intra- and inter-group relations in the context of oil and gas development in the Russian North are relevant far beyond the Arctic and the Russian Federation.

So far research on these relations has mostly been in the form of locality-based case studies. Most of them are ethnographic or social anthropological in nature, and their topical foci are diverse, including land tenure, traditional natural resource use and self-determination of indigenous groups (Anderson 2002; Habeck 2002, 2005; Novikova 1997; Roon 1999; Stammler 2003; Tuisku 2002 Wiget and Balalaeva 1997; Wilson 1999, 2002a); socio-economic issues, health, and demography (Pika and Bogoyavlensky 1995; Roon 2002; Zenko 2001); and strategies of adaptation to rapid social, economic, and environmental change (Dmitriev 2003; Gray and Stammler 2002; Stammler 2005a, 2005b; Wilson $2002 b, 2003)$. Further insights can be gained from cultural, anthropological, and ethnographic research in the same areas that does not focus specifically on relations between the oil industry and communities (Anderson 2000; Fondahl 1998; Kasten 2004, 2005; Ssorin-Chaikov 2003; Tishkov 2004; Vitebsky 2005). Regional analyses of Siberia and the Russian Far East from the perspective of economic geography and resourcebased development have also helped to inform understandings of multiactor relations (Bradshaw 2003b, 2005b; Hill and Gaddy 2003; Newell 2004; Thornton and Ziegler 2002).

However, the editors have observed the lack of a synthesis that brings together insights from analyses on a cross-regional basis, and the virtual absence of cross fertilization between case studies from northern Russia and those from other oil-producing regions of the world (e.g., Okoji 2002; Sawyer 2004; Wills 1991). Broad worldwide analyses 
such as those of Seifert and Werner (2005) include Russia but are more journalistic than academic in style and substance. One exception is the study by Haller and colleagues (2000), which brings case studies from regions as diverse as Papua New Guinea, Venezuela, Western Siberia, and Alaska into one common analytical framework in order to assess the influence of global tendencies on local communities.

In the study by Haller and colleagues (2000: 639-648), collective action by communities is identified as a crucially important factor determining the success of negotiations with the industry. Collective action, as framed by classic economic theory, means the collective behavior of groups towards a certain goal, for example to distribute goods in a fair way. Ostrom (2000) elaborates on this concept to analyze how commonpool resources are distributed and administered by groups. Frequently, actors choose individual maximizing behavior, such as over-grazing on common pasturelands, over collective action for the common good, such as limiting individual ownership of livestock (the so-called tragedy of the commons) (Hardin 1968). The central question is under which circumstances individuals display maximizing behavior, and when they act collectively. According to Olson (1965) and Ostrom (2002), collective action is more likely to happen, among other reasons, when resources are stationary and groups are small, because in such situations regulating access and exerting social pressure on group members costs less to individuals. In the study by Haller and colleagues (2000) the concept of collective action is applied to situations where mineral resource extraction is taking place in areas where indigenous communities live. It is argued that opposition or resistance to resource extraction is one example where the added value of collective action exceeds the value of individual maximizing behavior. While Haller's analysis is theoretically beneficial, communities appear mainly as victims of resource extraction who organize themselves in response to pressures from companies. We develop the argument further with our own concept of collective agency. Collective agency is the capacity of a group of actors to act together towards certain goals; as such it is a prerequisite for meaningful collective action. We apply this concept not only to community groups but also to other stakeholder groupings, such as employees in a company, or groups of oil companies involved in one region. In the cases we examine below, collective action may be directed toward anything from legislative reform, to environmentally sound construction work, to company-community negotiations.

As mentioned above, this issue has a strong focus on relations between oil companies and indigenous communities. We acknowledge 
the need to consider mixed communities and non-indigenous majorities in debates about oil industry impacts on local populations. We have heard and read the frequent concern of non-indigenous northerners, who have criticized the preoccupation of international actors, including academics, with indigenous peoples (e.g., Dobrinskii and Plotnikov 1997), and acknowledge that this may contribute to reifying ethnic boundaries and social tensions within communities. In fact, non-indigenous northerners have also developed strong emotional and social ties to the land (Round 2005; Vakhtin et al. 2004; Thompson 2004), and therefore we are supportive of initiatives that focus on mitigating impacts on people with a particular type of livelihood activity, such as hunting, reindeer herding, or gathering and fishing, regardless of their ethnicity. This sensitivity is not sufficiently discussed within industry circles at present, and yet is a potential risk for companies seeking to focus specifically on indigenous communities who live in an integrated way amongst non-indigenous populations. However, indigenous peoples' issues nonetheless occupy a particular place in the debates on community-industry relations. Reasons for this include the specific aspects of cultural heritage preservation and ethnic survival, issues relating to land and resource use and territories of traditional natural resource use, the development of indigenous rights legislation, and the increased politicization of the indigenous movement in Russia in recent years, particularly in the context of oil and gas development (Fondahl 1998; Habeck 2002; Okotetto and Forbes 1999; Roon 1999; Tuisku 2002; Wilson 1999, 2003).

In the absence of aspects of the legislative framework and of clarity in its implementation, local stakeholders often rely on "partnership" agreements with the extractive industry (Arakchaa and Zaidfudim 1999; Stammler 2005b). Ethnographic research by anthropologists and observations by indigenous activists have revealed that the quality and usefulness of such agreements for sustainable long-term development varies greatly (Novikova 1997; Stammler 2003). Popular protest actions, such as those of reindeer herders of the KMAO in the 1980s and the Sakhalin indigenous people in 2005, and the activities of international non-governmental organizations (NGOs), such as the campaign focusing on the Sakhalin projects, are a popular field of enquiry (Balzer 1999; Bradshaw 2005a; Lee 2005; Novikova 2000; Stammler 2003; Wilson 2002b). Public protests express the dissatisfaction of communities with what they perceive as ignorant practices by the industry. We believe these situations are often a result of substantial mutual misunderstandings. The present issue and the seminar series aim to provide more information to all sides and offer a neutral ground for debate. 


\section{The Russian Legislative Framework and International Standards-Focus on Impact Assessment}

In this section we discuss the regulatory framework that governs relations between oil companies and local communities, focusing in particular on the concept of impact assessment, as a topical and dynamic area of analysis and the main theme of three contributions to this volume (Spiridonov, Murashko, and Roon). We draw out similarities and differences between Russian and international approaches, highlighting the need to find ways to improve the dialogue between these approaches.

At a minimum, companies working in Russia are obliged to abide by Russian Federation legislation in all aspects of project implementation. Russian law is acknowledged to be comprehensive in the sphere of environmental protection. Environmental protection, access to information, and public participation in decision making are framed in the Russian Constitution (1993), and environmental protection standards such as those for pollution and waste disposal are often much more stringent than international standards. However, effective enforcement is often lacking at the regional and local levels, a problem attributed to lack of funding, and a lack of regulatory guidance on implementation. Other factors influencing the effectiveness of legislation include conflicts during the revision of certain laws (e.g., the Land Code), and the state of chaos in the Russian political and regulatory systems, leading to a lack of clarity in relations between different levels of power and confusion over the responsibilities of different agencies (Oldfield 2005; Oldfield et al. 2003). Pro-development lobbying and the power of President Putin also play a role (see below; also Spiridonov, in this issue; and Fondahl and Sirina, in this issue). It is also worth noting that the legislative framework for clarifying indigenous land and resource rights remains inadequate, a factor that hinders effective impact assessment and regulation of industrial activity on lands used for traditional livelihood activities (Fondahl and Poelzer 2003; Stammler 2005c; Wilson 2002a; see also articles by Murashko and Spiridonov in this issue).

The main Russian law that governs assessment of the environmental impacts of industrial projects is the 1995 law "On the Ecological Expert Review" (Ob ekologicheskoi ekspertize). Prior to commencement of a project, Article 3 of this law requires the submission of project documentation (including environmental impact assessments) to a panel of experts known as the State Ecological Expert Review (SEER) Commission. The experts review the materials and provide a positive or 
negative conclusion about the project. The "Environmental Impact Assessment (EIA) Procedures" of 2000 provide guidance on carrying out an EIA as part of the SEER process. ${ }^{11}$ Some activists argue that the SEER process is not always objective, and it is subject to powerful influence from pro-development interests. Articles by Spiridonov and by Fondahl and Sirina in this issue discuss the case of the Eastern SiberiaPacific Ocean Pipeline, whose negative SEER conclusion was initially rejected to allow the pipeline to pass within a kilometer of the World Heritage site, Lake Baikal, until President Putin stepped in to reverse the decision. Experts also note that there are no guidelines on impact assessment follow-up, and monitoring during the life of the project is not a mandatory requirement. ${ }^{12}$

As Murashko points out in this issue, consideration of socioeconomic impacts is mentioned in the 1995 law (Article 1), but they are left out of the EIA Procedures. This leaves a gap in Russian legislation for the assessment of project impacts on peoples' lives and livelihoods. Activists and academics are now aiming to close this gap by promoting the introduction of legislation relating to the concept of etnologicheskaia ekspertiza or "anthropological expert review" (Dmitriev 2003; Murashko 2002; see also articles by Murashko and Roon in this issue)..$^{13}$ Draft legislation states that an anthropological expert review would be conducted as part of a SEER. However, confusion has been caused by the conflation of impact assessment and expert review concepts in the literature on etnologicheskaia ekspertiza (see Roon in this issue). Murashko's article in this issue recommends expanding the law "On Ecological Expert Review" to incorporate etnologicheskaia ekspertiza and to draft additional "Procedures" for the assessment of socio-cultural impacts on local and indigenous communities. At the May 2006 annual conference of the International Association for Impact Assessment (IAIA), Pavel Filin from the Russian environmental law NGO Ecoline presented a current legal initiative to establish a process whereby ethno-cultural impact assessments are carried out alongside EIAs, and the documentation is submitted to a SEER panel that includes-in addition to ecologistsethnographers and anthropologists, who would thus carry out an anthropological expert review in parallel with the ecological expert review.

Discussions around anthropological expert review and ethnocultural assessment currently appear to focus primarily on indigenous communities. We would like to see legal initiatives that acknowledge the non-indigenous populations living in the same areas, who may or may not be engaged in similar resource-use activities. Evidence from Sakhalin and other areas reveals simmering resentment on the part of 
local non-indigenous populations when they see indigenous people receiving special attention from industrial developers.

International companies make efforts to respect the spirit of international conventions such as the Aarhus Convention on Access to Information, Public Participation in Decision-Making and Access to Justice in Environmental Matters (1998), and the Espoo Convention on EIA in a Transboundary Context (1991), despite the fact that Russia has yet to ratify them (see also the article by Fondahl and Sirina in this issue). ${ }^{14}$

Companies also have their own policies, including sustainable development principles, social performance policies, and policies for protection of health, safety and the environment. ${ }^{15}$ In addition to compliance with the requirements of national legislation, the corporate policies of multinationals such as Shell and BP increasingly require completion of an Environmental, Social, and Health Impact Assessment (ESHIA). ${ }^{16}$ This is an "integrated" assessment approach that incorporates environmental, social, and health impact assessment, though integration is often lacking in practice. To some degree the social impact assessment (SIA) that is part of an ESHIA addresses the gaps in Russian legislation discussed above. However, SIAs tend to lack specific analysis of cultural impacts, for example, of the type discussed by Fondahl and Sirina in this issue. Where project financing by international financial institutions such as the European Bank for Reconstruction and Development (EBRD) is involved, the project lenders may also request compliance with the World Bank Group "safeguard policies," notably the operational directive OD 4.20 "On indigenous peoples," (recently revised as the operational policy OP 4.10). ${ }^{17}$ In the Russian northern context, the Sakhalin-2 Project (Sakhalin Energy/Shell), which has completed both an ESHIA (2003) and an indigenous peoples' development plan (2006) according to OD 4.20, is a relevant case for analysis. ${ }^{18}$ Roon's article in this issue discusses the scope and results of the Sakhalin-2 Project SIA in the light of demands by indigenous activists for an etnologicheskaia ekspertiza of oil and gas projects on Sakhalin. Work has been done towards developing methodologies for ethno-ecological impact assessment in Russia (e.g., Stepanov 1999). However, Roon notes that certain specific types of methodology are lacking. When designing a household subsistence survey, Sakhalin Energy based their questionnaire on an Alaskan model and analyzed methods of assessing oil industry impacts on subsistence resources from the Exxon Valdez disaster (Field et al. 1999). ${ }^{19}$ In this issue, both Roon and Murashko argue for the integration of Western approaches into Russian academic literature, legislation, and practice, incorporat- 
ing aspects of the SIA and other Western initiatives such as the Akwe: Kon Guidelines (Secretariat of the Convention on Biological Diversity 2004).$^{20}$ However, they both acknowledge the problems associated with introducing new terminology into Russian legislation. Similarly, in our view, multinational oil companies proposing to carry out ESHIAs in the Russian North could learn from Russian experts and possibly incorporate some elements of the evolving Russian ethno-cultural assessment methodologies into the ESHIA. This may also inform development of the ESHIA concept for other regions of the world.

Several authors in this special issue highlight the importance of a holistic or "strategic" approach to the assessment of project impacts (see articles by Spiridonov, Murashko, and Roon in this issue). Strategic environmental assessment (SEA) is an integrated (environmental, social, economic) impact assessment approach that is focused not on individual projects but on development programs or groups of projects, and is applied at a much earlier stage than EIA or other impact assessments (see Spiridonov's article in this issue; also Office of the Deputy Prime Minister 2005). ${ }^{21}$ SEA is framed by the European Union Directive 2001/42/EC and the 2003 Protocol on SEA (known as the Kiev Protocol). ${ }^{22}$ Internationally, the process of developing and implementing SEA legislation is far from complete, and currently there is no legal basis for this in Russia at all. For the Russian context, Spiridonov (in this issue) suggests using existing tools to assess cumulative impacts at the earliest stages of project planning, for example by applying the SEER process to regional and sectoral planning documents (e.g., hydrocarbon extraction in a particular ecological region). However, adoption of SEA legislation is the responsibility of the federal authorities, and Spiridonov notes that political will to introduce SEA is lacking. Murashko (in this issue) similarly observes that with such a strategically important sector as the oil and gas industry, introduction of legislation that might limit this activity presents a considerable challenge.

In the absence of a complete legislative system, Russian NGOs and indigenous associations, such as Ekojuris, Ecoline, and the Russian Association of Indigenous Peoples of the North (RAIPON), work on these standards at the Russian federal level (see Murashko in this issue). ${ }^{23}$ Simultaneously, regional action groups such as Spasenie Iugry (KMAO), Yasavei (Nenets Autonomous Okrug [NAO] to the west of YNAO in northern European Russia), and Yamal Potomkam (YNAO) aim to establish a clear legal basis and reliable negotiation process between oil companies, authorities, and local populations (see Alferova in this issue). ${ }^{24}$ The activities of these NGOs include drafting legislation for their 
regional parliaments, and facilitating dialogue between indigenous communities and oil companies. Over 15 years this has led to close alliances between indigenous NGOs and the regional state in Western Siberia. While the NGOs started out providing independent criticism of Soviet policies, today some of them depend heavily on state funding and their status resembles a government-organized NGO (GONGO).

On Sakhalin there has been much less activity in the area of drafting legislation, although a draft law on etnologicheskaia ekspertiza has been considered by the regional Duma. There has also been less continuity within the Sakhalin indigenous movement, and relations between indigenous NGOs and the local and regional government are also much less close, although personal family ties exist between key individuals. Over the past decade, indigenous groups have been trying to develop a dialogue with the Western oil companies who are working in their region (see Roon's article in this issue). Today, Sakhalin activists favor relations with international companies and NGOs, arguing that relations with the government are unreliable, and they are concerned with what might happen if the government changes. ${ }^{25} \mathrm{Mu}-$ rashko (2006), for example, described a case in Kamchatka where a community was left without an agreement when a new regional governor came to power.

\section{The "Enabling Environment" for Relationship-Building}

While most stakeholders and observers agree that clear and wellimplemented legislation is a crucial precondition for effective regulation of the relations between companies, communities, and the state, misunderstandings and problems arise because little is known about how relationships are built and can be built "between the laws" or in the absence of consistent regulation. Anthropologists and ethnographers have contributed to shedding light on this question (Habeck 2002; Stammler 2002, 2005b; Tuisku 2002; Wilson 2003). Relationship building depends to a great extent on the "enabling environment," which is not only the legislative framework, but also various other factors that influence people's willingness and ability to engage in dialogue and the nature of that engagement. A range of factors contribute to the enabling environment, including economic influences, the legacy of Soviet-era practices, the involvement of Western companies, and the nature of relations between community groups and the local and regional government, as well as individual relations between actors. Sakhalin and Western 
Siberia provide contrasting experiences, with Sakhalin activists focusing on relations with the international community, and Western Siberian activists focusing more on building good relations with the local and regional governments. ${ }^{26}$

A major influence on the enabling environment for relationship building is exerted by a range of economic factors, acting at different levels. The economic effect of projects is greatly influenced by the agreements negotiated between foreign investors and host governments, such as the Sakhalin-1 and -2 project production sharing agreements (PSAs). Negotiated in the early 1990s, a period of considerable risk for foreign investors, the Sakhalin PSAs are criticised for not providing equitable benefits to the Russian parties (see Rutledge 2004 and Spiridonov in this issue). At the regional level, benefits from oil and gas revenues are spent in different ways. Sakhalin has set up the Sakhalin Development Fund, which uses bonus payments and revenues from Sakhalin's multinational offshore projects for infrastructure development, in addition to the direct investment in project-related infrastructure provided by the multinational companies (e.g., roads, health care, waste management). Sakhalin's oil company, Rosneft-Sakhalinmorneftegaz, has a long tradition of constructing public infrastructure in local communities (including hospitals, churches, and roads), based on agreements with the regional and local administrations. The KMAO, in a similar way to Norway, invests some of the money into a fund for future generations. The Western Siberian regions have also invested parts of their budget into specific programs to support the traditional lifestyle of their rural population. This is part of the reason why, for example, private reindeer herds in the KMAO and YNAO have been increasing after the collapse of the Soviet Union. Regional governments could afford to maintain subsidies for reindeer herding or even buy additional herds for their indigenous communities (Stammler 2005a, 2005b).

However, development of the energy sector is a key priority for Russia and one over which the government is increasingly seeking to re-exert control, reducing revenues to the regions and establishing a new "stabilization fund" in 2004 to centralize control over oil revenues and taxation in the context of rising oil prices (e.g., Vatansever 2005). Before 2002, many regions, such as Sakhalin and the YNAO, KMAO, and NAO were allowed to keep 60 percent of the tax charged for the "use of mineral resources" (izpol'zovanie nedrami). In 2002, a new federal tax on the "extraction of sub-surface resources" (na dobychu poleznykh iskopaemykh) was introduced in place of the previous tax, 20 percent of which went to the regional budget in the case of the YNAO and NAO. 
In 2005 the $\mathrm{YNAO}$ and NAO share was reduced to 5 percent, and as of 1 January 2006, nothing of this tax remains directly in the region; instead 100 percent goes to Moscow for redistribution nationally. Sakhalin has a similar story. This sudden reduction of revenues on which the Western regions of the Russian North in particular had relied increasingly since the early 1990s puts a lot of pressure on the regional budgets and local actors fear that this move will have a negative impact on the benefits that have been starting to trickle down to the local population. In 2004 the KMAO ( $\$ 4.0$ billion US) and Sakhalin ( $\$ 3.9$ billion US) were the leading Russian regions for foreign direct investment after Moscow ( $\$ 15.3$ billion US) (KMAO Department for Information 2005). However, many local expectations of improved living standards have yet to be realized, especially in the smaller communities (for Sakhalin, see Mitrofankin's article in this issue), and many fear that centralization of the revenue flow may make sustainable development of these communities more difficult to achieve. Despite their talk of promoting sustainable development, international oil companies and their lenders frequently state that they do not have the right to influence how governments manage project revenues. ${ }^{27}$

One obvious direct benefit to local residents is the prospect of employment. In 2005 the Sakhalin-2 Project (Phase 2) was employing approximately 17,000 people, of whom 70 percent were Russians. However, this is for the construction period, and employment will drop considerably during the operations period. Furthermore, in Sakhalin and elsewhere, most project workers are incomers, as many local residents do not have the necessary skills to work on the projects. Local capacitybuilding is a key requirement for channeling benefits to the region. In Western Siberia, this is institutionalized through partnerships between regional governments and Russian companies and has led to the establishment of educational institutions such as oil and gas universities (neftegazovye universitety) and technical colleges. In Sakhalin, the multinational companies offer training for local residents with a view to long-term employment. However, places are limited and there is considerable competition for them. The multinational projects also attract skilled experts away from the local oil industry and other sectors, such as the utilities, to work in better-paying jobs related to the projects. In some cases the projects require a knowledge of English language, a requirement that Mitrofankin (in this issue) claims can needlessly exclude local residents from opportunities. In local Sakhalin communities there is an increasing division between those who do work on the projects, with better work conditions, good pay and social security benefits, and 
those who do not work on the projects and who may be struggling to maintain their prior standard of living in the face of rising costs of housing and goods (see articles by Mitrofankin and Roon in this issue).

The former Soviet model of industrial enterprise had an element of "corporate social responsibility," which meant that enterprises were designed as "total social institutions" (Humphrey 1995: 7). This meant that the dominant industry in a community was responsible for social infrastructure (e.g., electricity supply, public baths (bania), refuse collections). In the post-Soviet era, responsibility for infrastructure development and maintenance was transferred from the state to poorly prepared local municipal authorities. Oil company compensation provided in the past for impacts on reindeer pastures was frequently used for general community needs (infrastructure, teachers' salaries) rather than the specific needs of the herders (see articles by Mitrofankin and Roon in this issue). In today's market economy oil companies are not "total social institutions," and do not claim to be. However, expectations are great, and local people are nonetheless disappointed that the multinationals on Sakhalin do not do more to resolve the municipal budget crises of the communities that they are working in such close proximity to. Moreover, the fact that revenue distribution itself is not resolving the crisis in local communities demonstrates an aspect of the "resource curse." In many other regions of the world such a situation has led to violent conflicts (Follath 2006; Seifert and Werner 2005).

Where local residents do not see the benefits flowing into their communities as they had hoped, and do not see companies performing their "corporate social responsibility," they see their only option of gaining some benefit from the projects as being via compensation. Administrations and activist groups-in Russia as in other regions of the world-may focus their attention and expectations on negative impacts (with a view to compensation), rather than work with companies to avoid and minimize harm and ensure long-term ecological and social sustainability of a project. In the NAO, for example, observers have noted that agreements (involving in-kind and financial compensation) focus too much on damage compensation rather than damage prevention. Both the company and local land users may be responsible for neglect of the mid-and long-term impacts, focusing instead on immediate profit-related goals. One way to address this issue is to involve representatives of an independent NGO in negotiations, such as a local branch of RAIPON, who would not directly benefit from the resulting profits.

Partly as a result of Moscow's centralization of the revenue flow, there have been increased efforts locally to control "social investment" - 
the additional funds that companies feed into local communities over and above revenues and compensation. This has resulted in battles between local stakeholders over control over these funds. In some cases, "social investment" in local communities has fostered a culture of dependency on oil company patronage, which is in some way an extension of the relationship with the Soviet state, who used to support local communities via the state-run enterprises, with additional social support for indigenous communities (e.g., transportation, provision of fishing equipment, boarding school education for children). Much is expected from large, rich institutions with headquarters external to the region, be they the Soviet Empire or a rich oil company. These local expectations have resulted historically and today in a loss of local initiative to solve problems independently.

Current efforts on the part of oil companies to make social investment more "sustainable" are hampered by uncertain relations with local governments, a lack of mutual trust and understanding, and disagreement over what can be called "sustainable." Western experts tend to consider it "unsustainable" to use social investment funds to provide indigenous enterprises with snowmobiles and fishing nets, which need constant repeat financing, or to build hospitals and housing. Infrastructure maintenance and public services salaries are considered to be the basic obligations of the administration (though this assumes effective "trickle down" of project revenues). Western ideas of sustainability focus more on capacity building, small business development, and environmental restoration and preservation, and Western companies tend to prefer channelling social investment (e.g., support for educational, health and cultural projects) directly to recipients, not via the local administrations. Thus, Western companies appear to be struggling with the integration of Western and Russian "sustainable development" values, while Russian companies, such as Gazprom, Rosneft, Lukoil, Surgutneftegaz, Yukos, and Sibneft, have considerable experience in developing social programs in partnership with local governments, sometimes with indigenous representatives, based on development models that may not be considered "sustainable" in the West (see Alferova in this issue). This is true for the Western Siberian regions, where we observe much path dependency with the Soviet Union.

When Soviet-era development started in Western Siberia in the 1970s, the companies and local administrations worked closely together, at least officially united by the common idea of "osvoenie severa" ("mastering the North"), and today there is still much personal continuity. Within the Soviet-planned economy, there was a strong idea of coexistence of 
indigenous communities and industrial activity. The idea was that, for example, reindeer herding could supply the food crucial for the industrial settlements. In this sense, the tundra was conceptualized as a huge open-air meat factory (Vitebsky 2005). We still observe the impact of that legacy when companies such as Gazprom hire senior indigenous leaders to organize their relations with the local population. As a generalization, one could say that the former Communist party "umbrella" provided a stable set of relations between very diverse land users, uniting them symbolically, and this symbolic sense of unity survives today. However, this does not mean that the impacts of industrial development were efficiently negotiated and mitigated at the time, or that they are today. Serious environmental impacts have been recorded as well as reports of marginalized indigenous people being deprived of their life on the land, and having to cope with alcoholism, drug abuse, and suicide in villages (Dobrinskii and Plotnikov 1997; Pika and Bogoyavlensky 1995; Stammler 2003).

\section{Indigenous Activism and Public Consultation}

Many of the activities of indigenous activists at a regional and local level have a peaceful and cooperative character. In comparison with protest or violent conflicts that take place over oil development elsewhere in the world, it is worth noting that in Russia most indigenous people are not against industrial development altogether, but their agency is geared towards improvement of the coexistence of local communities and industrial projects. However, there have been some notable examples of indigenous protest. In 1987 indigenous activists together with people from the tundra of the Yamal Peninsula protested in Moscow against the negative effects of the development on their and their reindeer's lives. In the end a moratorium was put on the development, and this was celebrated as one of the first big successes of the protests. However, more important may have been that at the end of Soviet Union there was no money or resources to develop these large deposits under these difficult circumstances. In the 1980s, the forest Nenets reindeer herder and poet Iurii Vella returned from Leningrad to live as a herder and to campaign against the oil company Lukoil working on his reindeer pastures, hunting, and fishing grounds in the $\mathrm{KMAO}$. His protests were screened on national Russian television, and he also attracted considerable international attention via the radio. His example might have contributed to the registration of many native land 
claims in the KMAO. These indigenous protests were probably motivated by the new spirit of freedom ushered in by Perestroika in the mid to late 1980s, in contrast to more recent protest actions (notably Sakhalin, see below), which have depended to a great extent on the involvement of foreign companies and the attention of the international community. Today, the relative freedom enjoyed by NGOs and public activists during the Perestroika era is considered to be a thing of the past-a notion emphasized by Putin's legislative amendments limiting NGO activity, which came into effect on 17 April 2006. ${ }^{28}$

In January 2005, Sakhalin's indigenous activists started up a protest action against the oil companies, demanding that the companies operating the offshore projects carry out an etnologicheskaia expertiza and that a dedicated fund be established for the development of Sakhalin's indigenous peoples (Wilson 2005; see also articles by Roon and $\mathrm{Mu}-$ rashko in this issue). This protest was immediately taken up by an international community already focused on Sakhalin as a result of NGO campaigns around the environmental sensitivities of the multinational projects (Bradshaw 2005a; Lee 2005; Spiridonov [in this issue]).

In the twenty-first century, protest activism of indigenous people has not been significant in Western Siberia. This is connected to the fact that both in the KMAO and YNAO there is comparatively more indigenous representation in the regional legislative and executive powers. ${ }^{29}$ Russian experts believe that these two regions have a relatively advanced and stable legal basis for regulating indigenous issues in the sphere of industrial production and land rights (see the article by Alferova in this issue). Observers have also noted that international and national NGOs find it more effective to target Western companies in their campaigns, due to the presence of an international community that is concerned with environmental and indigenous rights issues and can exert consumer pressure. Analysis of the Sakhalin projects in particular also demonstrates that conditionality of project financing provides NGOs and local activists with considerable leverage in their negotiations with oil companies (Bradshaw 2005a, 2005b; Lee 2005; Wilson 2002b; see also Murashko's article in this issue). ${ }^{30}$ Campaigns against oil development on Sakhalin have focused in particular on the Sakhalin-2 Project, which is using public financing from the EBRD and others. Multinational projects without the element of project financing (such as Sakhalin-1 that affects some of the same areas as Sakhalin-2) and projects operated by Russian companies in northern Sakhalin, Western Siberia and the European Russian North attract much less international attention, although environmental and social impacts of these projects may be the same or 
more significant. The increasing involvement of Western companies in Western Siberia and the European North of Russia is thus likely to have implications for public activism and the international community's awareness of the situation in these regions. These processes are worth being studied in detail; for example, the merger between Tyumen' Oil Company (TNK) and BP.

Activists claim that they try to influence companies via their lenders because the companies themselves are not transparent enough and do not engage in meaningful dialogue. Criticisms frequently focus on the nature of company-led public consultation (e.g., Sakhalin Environment Watch 1999). Public consultation is a mandatory requirement of the SEER process. ${ }^{31}$ Public consultation is also mandatory according to the corporate policy of companies such as Shell and BP and the requirements of the ESHIA. Guidance on public participation and information disclosure has been developed by international financial institutions. ${ }^{32}$ However, there are no standard procedures for carrying out public meetings-such procedures would be very difficult to develop, as specific requirements vary from place to place. In practice, company experts themselves decide when and where to hold meetings, the format of the meetings, and to a great extent the nature of the information disclosed. NGO reports, public sources, and participant observation by anthropologists, have shown that the lack of a standard process and any obligation of follow-up are major shortcomings of the consultation process. What is called consultation in press releases is in some cases in practice closer to controlled information dissemination about the projects, while adaptation to the new situation is left to the people themselves. Even where these dialogues provide a forum for local people to express opinions, in many cases these are not considered in the planning or implementation of the projects (Novikova 1997; Stammler 2003; Steheli-Pfister 1995; see also the article by Fondahl and Sirina in this issue). Above all, people need to feel they are involved in a genuine dialogue, where they are being listened to and their concerns and suggestions are being incorporated into project planning.

\section{The Importance of Collective Agency}

As we have mentioned above, relationship-building in practice depends on the collective agency of the stakeholders in the local community on the one hand and the developers on the other. The multiplicity of actors in huge oil and gas extraction projects makes communication problem- 
atic between project staff and communities at different levels, and indeed between different sections of a project. Haller and colleagues (2000: 638-647) compare different cases of oil extraction around the globe in an attempt to explain why in some cases communities fight against oil extraction, and in other cases not. According to Haller and colleagues, communities that do not demonstrate resistance to oil extraction tend to display a lack of collective action, but the extent of collective action (mostly in the form of collective resistance) does not necessarily depend on the amount of damage caused by the industrial activity. In extension to this, we argue that collective agency-as the capacity for collective action within a stakeholder group-can be analyzed not only in relation to local communities and their capacity for resistance to oil companies, but also in relation to project implementers and their capacity for dialogue with local communities. Individualism and a lack of coordination on both sides has led to inadequate solutions in the past and present (e.g., Novikova 1997). Large project consortiums consisting of multiple companies find it difficult to act collectively, especially in initial project phases where much work is carried out by contractors. Mitrofankin points out in this issue that the most direct and significant relations between a company and local communities are forged via the contractors who carry out construction in and close to the communities. However, in the case of large-scale and multiple projects, local communities and even company representatives may have difficulty determining what work is being done by which company, fulfilling whose order. A daughter company in a Russian region or contractors working in outlying construction sites may not follow the policies established by headquarters. Sakhalin Energy for example found it difficult to manage Russian contractors constructing pipeline river crossings. Many misunderstandings within a project are due to poor communication, poor management, and cultural differences. Contracted teams in Russia today may be Japanese, Turkish, Italian, French, Russian, Ukrainian, or other nationalities. A notable issue is the frequent clash of Russian and Western management styles and scientific approaches, and a lack of trust and understanding between Russian and Western experts. This may have contributed to Amoco pulling out of the Yamal gas deposits in 1996, where they had been involved with Gazprom since 1989.

While a lack of collective agency may be to blame for poor coordination, management, and communication, in practice issues are frequently resolved at the local level through individual relations and initiative. At the local level, company workers are known to engage in trade and barter with herders and fishermen, often without the knowl- 
edge of their headquarters. Sometimes this practice is seen as mutually beneficial (Stammler 2005a, 2005b). In other cases, local arrangements may lead to some communities getting better deals than others (e.g., as described by Einarsson et al. [2004: 142f]). In some cases, for example in the trade of reindeer meat for vodka, the practice is very damaging for the local herders. This diversity of practices demonstrates that relationships between companies and local communities depend to a great extent on the will and capacities of individuals. Some local workersparticularly newcomers from other regions-are often afraid to engage in relations with local people too independently for fear of contravening company policy, so corporate policies are used as excuses to refuse requests from local people for assistance. This causes irritation among indigenous land users, who feel that company employees disregard the zakon tundry (the law of the tundra), which is based on generalized reciprocity (Stammler 2005a). For example, why should an oil worker refuse to provide herders with fuel for their kerosene lamps or snowmobiles when the oil and gas lie under their reindeer pastures?

Individuals can act and react quickly and spontaneously to solve immediate problems. A Western oil company may have a corporate procedure for resolving community grievances (involving large amounts of paperwork passed through a management hierarchy). Ideally company employees should be familiar with the procedure and should work collectively to implement it. However, in practice issues are often resolved at the local level by a swift transaction between a subcontractor manager and the complainant. Indigenous residents can come to substantial agreements with oil or gas workers in face-to-face negotiations, which are also indispensable for exchanging knowledge and providing mutual assistance and advice. For example, Sibneft-Noyabrskneftegaz relies on Khanty and Nenets intimate knowledge of the land to monitor pipelines and report damage. The households receive equipment and compensation for this work and broader economic assistance. ${ }^{33}$ On the other hand, such individual agreements can be and have been controversial (Novikova 1997; Stammler 2003; Wiget and Balalaeva 1997). The question is to what extent individuals gain benefits for themselves while excluding the rest of the community - a classic dilemma of collective action (Ostrom 2002). There were also cases where companies made use of the lack of collective agency among indigenous people, who lived isolated in the taiga without access to infrastructure and communications with one another. Since 2001 in the KMAO, some of the camps in the taiga have mobile phone coverage areas, and the regional government has passed framework legislation giving the indigenous people land titles for 13.8 
million hectares (more than one-quarter of the KMAO territory for less than 5 percent of the population), which are now legally registered as territories of traditional natural resource use. While this would not be enough for a major reindeer-herding region such as the YNAO, it is still the most far-reaching set of indigenous land titles in the Russian Federation today, and representatives from other regions see this as an example of the best possible solution in the current situation (e.g., Peskov 2003). These developments and lessons from the past have led to a process whereby individual land holders sign compensation agreements with oil companies according to a standard template (Vasin 2003). This mechanism to some extent overcomes the disadvantage of fragile, individual, ad hoc agreements. However, if there is a change of project personnel, agreements may need to be renegotiated with no guarantee of the same deal. Therefore continuity of personnel is beneficial (Stammler 2005b). This has been demonstrated on the Bovanenkovo and Sabetta deposits on the Yamal Peninsula, where relations between gas workers and herders have been stable in spite of several bankruptcies and considerable company restructuring since the break-up of the Soviet Union. ${ }^{34}$

The above-mentioned shortcomings of individual agreements and negotiations can largely be overcome in cases where both sides develop effective instruments for collective action. In many cases both the companies and the indigenous people do not know whom to talk to, or whether their interlocutor really represents the community or institution he/she purports to speak for. We argue that collective agency-the capacity to work together-is a precondition for predictable and reliable relations on both sides. For a company, effective management systems, good communication, and clear assignment of responsibilities are ways to ensure a certain amount of collective agency in order to promote positive relationship-building in local communities and minimize damage due to project activities in those communities. However, as we noted previously, there is some advantage in allowing individuals to resolve matters at the local level themselves. Therefore managers based in corporate headquarters need to have a good understanding of the local situation; they need to trust local (subcontractor) managers and have effective systems of communication with local project sites.

Within the community, collective agency needs to be built through effective institution building. Over the past 15 years the indigenous communities of Western Siberia have made considerable progress in coordinating their actions, and it is no coincidence that indigenous representation is best institutionalized in regions with industrial activity. 
After years of paternalism, the oil and gas industry in the late 1980s was a common adversary for communities seeking to regain control over their lands. The 1990s brought major achievements in civil society development in these resource-rich regions, whereas in the twenty-first century, these achievements have become increasingly co-opted by an authoritarian federal government.

One way to enhance dialogue between groups and overcome the lack of collective agency within stakeholder groups has been tried in the NAO. Yasavey, the indigenous people's association, jointly with the NAO Association of Geologists invited companies for roundtable discussions about the consequences of ongoing oil developments. Roundtable discussions are thought to establish good conditions for more formal dialogue, without immediate or binding implications. Similar roundtable discussions have also taken place in Vladivostok and the $\mathrm{KMAO}$, but in the NAO, they have best met the challenge of dealing with specific problems of individual oil projects, particularly in the absence of clear federal and regional legislation. The principles of dialogue were: transparency, neutrality, objectiveness, consideration of national and international experience, and monitoring of project performance (Peskov 2003). The working group and the roundtables became important, flexible instruments of conflict resolution, without legislation or written agreements. Western companies, although invited, were reluctant to take part, arguing that their own guidelines and corporate policies sufficiently regulate dialogue. This roundtable model could be replicated in other regions where the legal basis is inadequate and the regional state is weak, as was the case in the NAO for most of the post-Soviet period. However, the precondition for effective functioning is the presence of an organizational team that is perceived to be neutral enough to give a voice to all opinions. In the NAO, balance was assured through Yasavey's alliance with the geologists.

The case of the Sakhalin-2 Project demonstrates how consultation style can influence relations. As part of the 2003 SIA, Sakhalin Energy initially focused their consultation efforts primarily on the indigenous reindeer herders, who were identified as "directly impacted" because project pipelines cross their pastures. Mitrofankin and Roon in this issue note that the meetings that Sakhalin Energy organized with the herders on the reindeer pastures were well received locally. Similarly when the CEO of an oil company visited reindeer herders in their nomadic chums at the Tambeiskoe deposit on Yamal Peninsula, this increased mutual trust between the company and the herders. However, despite 
their innovative engagement with the herders, the comparative lack of attention paid by Sakhalin Energy to the (indirectly affected) indigenous fisher folk and the indigenous leadership was probably a factor that led to the January 2005 protests. In 2005-2006, Sakhalin Energy developed its "Sakhalin Indigenous Minorities Development Plan" (SIMDP) as a response to the protests. ${ }^{35}$ Indigenous representatives have been involved in in-depth discussions with company experts relating to project impacts and mitigation measures, and in decision-making on distribution of development support funds to the indigenous community. The SIMDP also focuses on capacity building of indigenous leaders and activists. Sakhalin Energy has learned lessons from the SIMDP experience, such as the value of working with elected representatives, where previously they had questioned their representativeness (see Roon in this issue) and open and direct dialogue between the company's technical experts and indigenous representatives. Challenges to effective implementation include the factionalism within the indigenous community; the need for long-term commitment and allocation of resources on the part of the company; and alienation of the non-indigenous community, which makes up 93 percent of the local population of northeastern Sakhalin. A key challenge is finding a balance between company efforts to introduce "sustainability" into social investment spending (e.g., through increased accountability or through enterprise development programmes) and the expectations of local indigenous residents for less "sustainable" forms of support for traditional livelihood activities (i.e., direct donations with minimal reporting).

Discussions relating to the effect of the oil industry on the local natural resource base are not taking place with Rosneft-Sakhalinmorneftegaz, who has been engaged in onshore oil and gas development since the 1920s, despite the fact that most of the indigenous peoples' concerns relate to phenomena such as "fish smelling of oil," which are more likely to be a result of the onshore oil industry, or indeed natural seepage of oil (see the articles by Mitrofankin and Roon in this issue). This demonstrates the need for a broader engagement and a greater degree of collective agency among oil companies working in one region. Here a "Sakhalin association of oil producers" would enable development of more holistic approaches to assessment, mitigation and development initiatives-including strategic assessment and possibly ethno-cultural assessment-as well as scientific baseline research. We also suggest the need for industry standards to guide the negotiation of agreements between companies and communities. Such standards do exist (e.g., Rozon 2003) and could be modified as necessary for the Russian northern context. 


\section{Conclusions}

Given the strategic importance of Russia's oil and gas reserves, expansion into ever more sensitive areas of the Russian Arctic is likely and the challenges to ensuring sustainability of development, with equitable benefits to local communities, will become ever greater. Economic imperatives will continue to dominate over environmental and social aspects in government decision making. Western and Russian observers and activists call for establishment of a more robust legal framework in relation to indigenous rights, particularly to land and natural resources, and to the assessment and long-term monitoring of the social and environmental effects of project-related activities. However they are also aware of the many obstacles-not least political will-to introducing new legislation to control the activities of Russia's oil and gas sector. Although the Putin administration emphasizes its commitment to law and order, obstacles increase with the return of the federal government to more authority and centralization. With this strong center basing its power mainly on mineral resources, negative effects as analyzed by scholars of the resource curse theory for other "petro-states" might become visible soon.

Contributors to this issue highlight two areas of impact assessment that are lacking in Russian legislation: assessment of socio-economic and cultural impacts on local communities; and strategic/cumulative impact assessment. We emphasize the importance of dialogue between Russian and Western experts around these concepts. We also identify as important the lessons learned from other areas of the world with similar experience and recommend more exchange of experience at the practical and theoretical levels, possibly through establishment of international networks of experts focused on particular areas of impact assessment.

While we acknowledge the importance of the legal and regulatory sphere, we have introduced some of the rich and diverse experiences in the coexistence of oil and gas projects and indigenous communities, where a stable legislative framework is currently lacking. Practical agreements often precede laws, demonstrating that a legislative base is not essential for the start-up of dialogue. Legal shortcomings do not need to be an excuse for inactivity or poor practice. Experience from the ground ideally informs and shapes legislation, while clear legislation, effectively implemented, provides a common standard and security on which both companies and communities can rely. Thus, rather than being mutually exclusive, laws and individual agreements should complement one other. 
With examples mainly from Sakhalin and West Siberia we have demonstrated the diversity of relationship-building approaches, ranging from close cooperation between regional government, indigenous households, and oil companies in Western Siberia to a partnership between indigenous peoples and a Western company on Sakhalin. Comparing the Sakhalin and the Western Siberian cases, the most striking differences are the role of the regional government and the prominence of international involvement in the regions. Our comparison demonstrates how a regional state can remain strong, can significantly influence global developments, and can have a strongly unifying impact on corporate and local actors involved. On the other hand, the combination of a relatively weak regional state and the presence of strong "global players," as on Sakhalin, results in more direct relationshipbuilding between local actors and global players. We have shown that both models have their positive and negative sides, and we call for more detailed comparative research in order to combine good practices from both types of approach in the future.

We argue that the "enabling environment" is very important for building relations between communities and oil companies. Various factors influence the enabling environment, including economic factors such as revenue distribution. Non-equitable distribution of revenues hinders attempts to make development sustainable and leads to tense relations, with battles over the distribution of social investment funds. Existing practices have also shown that the current focus on damage compensation in many project agreements is not sustainable. While we agree that all damages should be compensated, a stronger focus on damage prevention would significantly improve the conditions for peaceful and fruitful coexistence between subsurface resource extraction and on-surface resource use. However, we acknowledge that this can only be successful in combination with careful planning for equitable benefits distribution to the immediately affected population and the region as a whole.

In our experience, Russia's indigenous peoples are essentially focused on peaceful co-existence with the oil and gas industry. The postPerestroika era gave rise to hope and increased activism, but now collaboration appears to be a more effective strategy with the government in Western Siberia. With international companies, as the Sakhalin case study demonstrates, protest is effective because of the attention from the international community and the particularly strong "enabling" influence of project financing. The way a company carries out public consultation and organizes other forms of governance are major factors in the effectiveness of relations between that company and the local com- 
munities where it works. Consultation needs to lead to action within a company and people need to feel they are involved in a meaningful dialogue and are able to influence project decision-making. It is important that consultations be conducted at a time and place suitable for local participants and at a stage in project development where recommendations and concerns of local people can still be included in the project design. Consultation should be carried out by personnel with experience in local relationship building. We also emphasize the importance of feedback mechanisms and monitoring. When local communities are participating in a long-term partnership, they can provide an effective channel for feedback about the problems and benefits of the ongoing implementation of the project. We strongly support efforts to incorporate long-term monitoring as a mandatory part of any new legislative initiatives relating to impact assessment.

Local, indigenous, and traditional knowledge has a great potential to be used for impact assessment and monitoring of industrial development when it is incorporated by skilled personnel that act as effective "cultural translators." Differences in practices, worldviews, and approaches can lead to misunderstandings along the line of scientific and practical knowledge. These generate different understandings of sustainable development among stakeholders. We argue further that even where oil companies are jointly run and owned by Russian and Western shareholders, differences in management cultures lead to frequent miscommunications. These different practices are also the outcome of the path-dependent development that many companies have experienced after the collapse of the Soviet Union.

Collective agency on the part of both the companies and the local communities makes relationship-building more reliable. Fifteen years after Perestroika, we observe among indigenous communities an increase in their capacity to join forces in the pursuit of common goals. They are increasingly being proactive in organizing relations with companies and the state. However, we note significant regional differences in the way that collective agency is used, ranging from opposition to industrial development to cooperation with companies or the administration. Given the authoritarian stance of Putin (exemplified in his response to the Eastern Siberia-Pacific Ocean Pipeline project and his legislative reform relating to NGOs), we acknowledge that an increase in collective agency on the part of communities may not be enough to ensure effective involvement of local people in decision-making relating to oil and gas development at all levels. However, we maintain that good working relations between communities and company represen- 
tatives can help to mitigate project impacts and facilitate coexistence beyond the force of laws and big politics. This will be most successful in those cases where there is personal continuity in the people taking part in the engagement. Public pressure groups will continue to play crucial roles in the future. Analysis of the personal dimension on the ground is among the strongest contributions by anthropologists working in Russia and will continue to be important (e.g., Ssorin-Chaikov 2003; Stammler 2005a; Yurchak 2005).

A lack of collective agency on the industry side can be observed between mother and daughter companies, headquarters and branches, contractors and subcontractors. It is also worth investigating the performance of joint ventures in Russia from the perspective of collective agency, including the way that they incorporate different management and scientific cultures and technical practices, as well as their policies of engagement with local communities and the state. From both regions we conclude that personal relations and continuity of relations between oil company workers and community representatives can influence the success of company-community dialogue. Characteristics such as selfinterest, mistrust, factionalism, and a lack of cultural awareness can undermine dialogue. Successful examples show that a productive culture of dialogue requires equal efforts on both sides (Stammler 2005b). Rather than focusing on encouraging indigenous stakeholders to learn the language of companies and extractors, it also requires that industrial workers learn the ways of talking and knowing of the indigenous people. Long-term, trust-based relationships are more likely to be successful.

While analysis of current practice, literature, and the fluid legal situation has produced valuable lessons to learn, it has revealed even more questions and several significant areas requiring further research. First of all in the area of impact assessment, we recommend a comparative analysis of Russian and Western standards, particularly relating to assessment of socio-economic and cultural impacts on local populations. In general there is a need for a more open and productive dialogue around this theme between Russian and Western researchers and practitioners, together with local community leaders and activists. For this, a relatively neutral space is needed for the dialogue to escape the emotional nature of current public debates. Similarly a great deal of useful comparative research can be made into the concept of SEA, and the possible applications of this concept to Russian planning processes. Land rights are already a popular research topic, but there are still many areas that remain to be explored, particularly in relation to land claims in the context of oil and gas developments. 
Further research needs to be carried out into monitoring and feedback mechanisms related to impact assessment, and related consultation and participation processes. This has relevance for holistic approaches that go beyond corporate governance practices of a particular company, and focus more on assessing how livelihoods and ecosystems change in general under industrial development. Academic debates can be broadened and enriched by non-academic input and exposure to policy implementation issues.

With regards to lessons learned, there needs to be more crosscutting academic analysis, both geographically and thematically. Theoretically, one avenue with great potential to explore in assessing the implementation of industrial projects and project negotiations among stakeholders is the application of neo-institutionalist approaches (Ensminger 2002; Finke 2004). A comparative analysis of the factors that increase or reduce transaction costs comparatively across regions and management practices might generate important insights both for academic understanding and practical use.

Western oil companies and local and regional administrations need to reach a mutual understanding of various "sustainable development" concepts in order to build effective partnerships to this end. This is one area where ethnographic research-in-depth study of local societiesis very relevant. Such research can usefully inform the actions of oil and gas practitioners, community leaders, and the authorities, providing insights into power relations, stakeholder interactions, and community dynamics. The role of anthropologists as mediators and "cultural translators" is worth exploring more in the context of oil and gas development. Locally grounded ethnographic research is also important for the development of theory, policy, and corporate engagement and communication strategies. A good understanding of corporate dynamics and company behavior is also important for theoretical debates about institution building, institutional performance, and the "anthropology of hydrocarbon resources" that is starting to develop as an academic reaction to this critical contemporary theme.

We also need more critical analysis of public statements from all sides of the debates around resource extraction-including local community representatives, NGO campaigners, and oil company public relations departments. This is particularly important given the extensive use of the Internet for publicizing and accessing information. All of these sources of information have their own bias, and a search for the whole picture in its complexity somewhere in amongst the varied viewpoints and rhetoric can be done, for example, using the tool of critical 
discourse analysis (Blommaert and Bulcaen 2000; Chouliaraki and Fairclough 2000; Fairclough 1995). If analyzed critically and objectively, public statements can provide valuable insights into the motivations of key players in these complex global and local battles for environmental protection and social justice.

The articles in this special issue demonstrates the need for ongoing dialogue and further development of imaginative ways to achieve this. We argue that lessons learned from existing experience can be used towards establishing a new culture of dialogue between communities, companies, and the state. With lessons being learned from research in the Russian North, Siberia and the Russian Far East, the significance of these regions is not only growing in terms of strategic fuel suppliers, but also for shaping our general understanding of relations between local and global actors in the context of mineral resource development in sensitive environments.

\section{Acknowledgments}

We acknowledge the importance of discussions that took place among participants of the seminar series "Trans-sectoral Partnerships, Sustainability Research and the Oil and Gas Industry in Russia" in informing and inspiring some of the content of this article and the volume as a whole (see: http://www.spri.cam.ac.uk/events/russianoil). The seminar series would not have been possible without a grant from the UK Economic and Social Research Council (ESRC) and the organizational support of the Scott Polar Research Institute (University of Cambridge), the Department of Geography at the University of Leicester, the Centre for Environmental Policy and Governance at the London School of Economics, and the research and consulting firm Environment \& Community Worldwide. Specifically, we would like to thank our co-organizers Piers Vitebsky, Michael Bradshaw, and Andy Gouldson.

We would like to thank the contributors to this volume for their valuable and stimulating discussions during the review and editing process. We are grateful to Jonathan Oldfield and the anonymous reviewers of this article for their useful comments. We would also like to thank our local informants and friends, who for many years have been providing support, insights, and inspiration. In addition, Emma Wilson would like to thank her colleagues at Sakhalin Energy, and one expert from Shell who reviewed this article. Finally we would like to thank Sibirica editor Alex King for reviewing this article and for his advice and encouragement during the completion of this publication. 
Florian Stammler is an anthropologist specializing in industrial development, land use, and indigenous peoples in the Russian North, associate of the Scott Polar Research Institute at the University of Cambridge, and a senior researcher of the Arctic Centre at the University of Lapland. While he did his PhD research in West Siberia, Stammler has done fieldwork and published on indigenous peoples, reindeer herding, and mineral resource extraction in five regions of the Russian North. His recent monograph "Reindeer Nomads Meet the Market" is an in-depth analysis of Arctic pastoralism in Yamal, a region with intensive mineral resource extraction.

Emma Wilson is a freelance social-environmental consultant, director of Environment \& Community Worldwide, Ltd., and associate of the Scott Polar Research Institute at the University of Cambridge. Emma first visited Sakhalin Island 12 years ago. She has worked there as an environmental activist, $\mathrm{PhD}$ researcher, and latterly as consultant to Sakhalin Energy Investment Company Ltd. (Shell). Emma has also worked with conservation organizations in Russia and the former Soviet Union, and as a consultant to Shell in Qatar. She has published several academic articles and is a regular speaker at academic and practitioner conferences. From September 2006 Emma will be senior researcher in business and sustainable development at the International Institute for Environment and Development (IIED) in London.

\section{Notes}

1. ESRC is the UK Economic and Social Research Council. More information about the seminar series can be found at http://www.spri.cam.ac.uk/ events/russianoil/. (All web references are current as of 18 July 2006).

2. The Sakhalin project PSAs have proven to be controversial and critics argue that they do not result in equitable benefits to the Russian party (see for example Rutledge 2004). Other PSAs include the Khariaga project in the Nenets Autonomous Okrug (NAO), which includes TotalFinaElf (50 percent shares), Norsk Hydro (40 percent), and Nenets Oil Company (10 percent); and Shell's Salym Project in the Khanty-Mansiisk Autonomous Okrug (50:50 with Sibir Energy Plc).

3. While some sources translate the administrative entity of okrug as "district," others refer to it as "region." To avoid confusion, we leave it in its original Russian form. Similarly we leave the Russian words krai and oblast' (province or region) in their Russian form. 
4. The Rosneft flotation is another development to watch, with BP and others expected to buy shares (while 75 percent of shares are retained by the Russian government): http://observer.guardian.co.uk/business/story/0,1821251,00.html

5. E.ON is a German energy provider that was established when German energy distribution and supplies were liberalized and privatized. The company became a major international player when it merged with Germany's biggest gas company, Ruhrgas. BASF is one of Germany's big chemical companies, and through its daughter company, Wintershall, the number two on the gas market. They established with Gazprom the joint venture WINGAS in 1990 for the realization of the Yamal-Europe gas pipeline project.

6. For more information on the Eastern Siberia-Pacific Ocean Pipeline, see http://www.transneft.ru/Projects/Default.asp?LANG=EN.

7. Sakhalin produced 16,000 tons of oil in 1926 and 505,000 tons in 1940 (Vysokov 1995).

8. For more information about Rosneft' and its subsidiaries, see http:// www.rosneft.com/english/.

9. Exxon Neftegaz Ltd.'s shareholders are ExxonMobil; the Russian companies Sakhalinmorneftegaz-Shelf, RN-Astra; the Japanese company, Sakhalin Oil and Gas Development Co. Ltd.; and India's ONG-Videsh. Sakhalin-1 is a $\$ 15$ billion US project with total recoverable reserves of an estimated 307 million tons of oil and 485 billion cubic meters of natural gas (see Sakhalin-1 Project Web site at http://www.sakhalin1.com/). Sakhalin Energy Investment Company Ltd.'s shareholders are Shell, Mitsui, and Mitsubishi. Sakhalin-2 ( $\$ 20$ billion US) has recoverable reserves of 150 (195) million tons of oil and 500 (800) billion cubic meters of gas. When complete, Sakhalin-2 is expected to deliver 9.6 million tons of liquefied natural gas (LNG) per year (7.5 percent of current global demand) and up to 150,000 barrels of oil a day. See http:// www.mitsubishicorp.com/en/bg/energy/usakhalin.html and http://en.rian .ru/business/20060406/45391158.html. See also articles at: http://www .sakhalinenergy.com/en/media.asp.

10. For more information about AMAP's oil and gas assessment project, see: http://www.amap.no/. The Arctic Council is an intergovernmental organization of Arctic countries that provides a framework for coordinating policies and directing development in the Arctic. The fact that the Arctic Council initiated a report on this topic is revealing about the political priority given to circumpolar hydrocarbon development.

11. The Russian name for the Environmental Impact Assessment Procedures is Polozhenie ob otsenke vozdeistviya namechaemoi khoziaistvennoi $i$ inoi deiatel'nosti na okruzhayushuyu sredu (literally the procedures for assessment of the impact of a proposed commercial or other activity on the environment). The Russian term for Environmental Impact Assessment is Otzenka vozdeistviia na okruzhayushuyu sredu or OVOS.

12. This is a problematic matter not only in the Russian context and has been discussed widely at the international level. See Impact Assessment and 
Project Appraisal, vol. 23, no.3, September 2005 (special edition devoted to EIA follow-up).

13. The authors have chosen this translation because the English word "anthropological" is more commonly understood than "ethnological" and because the Russian term expertiza is generally translated as "expert review." However, there are some problems with the term etnologicheskaia expertiza, as the concepts of expert review and ethno-cultural assessment have been conflated in the one term in current literature. This is why Tatiana Roon and Olga Murashko in this issue insisted on keeping the Russian term etnologicheskaia expertiza in the translations of their articles. Where the meaning of etnologicheskaia expertiza is unclear, we have therefore also maintained the Russian term in this article.

14. See for example Sakhalin Energy's Public Consultation and Disclosure Plan (2005) (http://www.sakhalinenergy.com/en/documents/doc_lender_ soc_5.pdf) and the EBRD's Environment Policy (2003) (http://www.ebrd.com/ about/policies/enviro/policy/policy.pdf). More information on the Aarhus and Espoo Conventions can be found at http://www.unece.org/env/pp/ and http://www.unece.org/env/eia/ respectively.

15. These policies are accessible on the company Web sites, for example: Shell (http://www.shell.com); BP (http://www.bp.com); Rosneft (http://www .rosneft.com/english/); and Sibneft (http://www.sibneft.com/).

16. To view Sakhalin Energy's ESHIA, go to: http://www.sakhalinenergy .com/en/library.asp. Select "Environmental - " "Social - " or "Health Impact Assessment (2003) and Addenda (2005)"; also see the BTC Investment Web site (http://www.btcinvestment.com/).

17. Sakhalin Energy, for example, has made a public commitment to comply with the spirit of the operational directives 4.20 (on Indigenous Peoples) and 4.30 (on Involuntary Resettlement), while keeping in mind the new operational policies (in particular OP 4.10 on Indigenous Peoples), which were approved after Sakhalin Energy had partially developed its project documentation. In line with these policies, Sakhalin Energy has produced an Indigenous Peoples' Development Plan and a Resettlement Action Plan in addition to its other project documentation. View documentation at http://www.sakhalinenergy.com/ en/library.asp. Select "Social Impact Assessment (2003) and Addenda (2005)."

18. See the Sakhalin-2 Project documentation at: http://www.sakhalinenergy .com/en/library.asp?p=lib_sel_sia20032005.

19. The development of the Alaskan oil industry and in particular the Exxon-Valdez disaster have provided a wealth of experience in the analysis of subsistence resource use and oil industry impacts on subsistence food supplies. See: http://www.subsistence.adfg.state.ak.us/; http://www.subsistence.adfg .state.ak.us/TechPap/tp284Twentyfiveyears.pdf; and http://www.subsistence .adfg.state.ak.us/geninfo/publctns/askinst.cfm

20. The Akwe:Kon Guidelines, approved in 2004 by the Parties to the Convention on Biological Diversity, are "voluntary guidelines for the conduct of cultural, environmental and social impact assessments regarding developments 
proposed to take place on, or which are likely to impact on sacred sites and on lands and waters traditionally occupied or used by indigenous and local communities" (see http://www.biodiv.org/doc/publications/akwe-brochure-en.pdf).

21. The Development Action Committee of the Organisation for Economic Co-operation and Development recently published guidelines on applying SEA in development cooperation. They define SEA as "analytical and participatory approaches to strategic decision-making that aim to integrate environmental considerations into policies, plans and programmes and evaluate the inter-linkages with economic and social considerations." See http://www.seataskteam.net/.

22. The text of the EU Directive 2001/42/EC on the assessment of the effects of certain plans and programs on the environment (known as the SEA Directive) can be found at: http://europa.eu.int/comm/environment/eia/ full-legal-text/0142_en.pdf. The Kiev Protocol is part of the Espoo Convention on EIA in a Transboundary Context. The protocol will come into force when the 16th state has ratified it. See http://www.unece.org/env/eia/.

23. The Web sites of Ecojuris, Ecoline and RAIPON can be viewed at: http://www.webcenter.ru/ ecojuris/rindex.htm; http://www.ecoline.ru/; http://www.raipon.org/.

24. Spasenie Yugry means "Save the Yugra" (the traditional local name for KMAO; see http://www.admhmao.ru/politics/spas_ug/spas_ug.htm); Yasavei means "knowledgeable skillful person" and "Yamal-Potomkam" means "Yamal for our descendants." (http://www.raipon.org/yasavey).

25. See Indigenous Peoples' Workshop report from the fourth seminar in the series "Trans-sectoral Partnerships..." This will be on the seminar series Web site as of September 2006. See http://www.spri.cam.ac.uk/events/russianoil/ seminar_4.html.

26. See report of fourth seminar in the series "Trans-sectoral Partnerships..." at http://www.spri.cam.ac.uk/events/russianoil/seminar_4.html.

27. Despite commitments to the "publish what you pay" principle, the EBRD states on its Web site that "it is up to the Russian government how it shares out Russia's part of future revenue from the project with the Sakhalin Regional Administration." See http://www.ebrd.com/country/sector/natural/ projects/sakhalin/facts.htm

28. According to these legislative amendments, NGOs have to re-register and their access to foreign funding is greatly reduced.

29. For example, the president of RAIPON, Sergei Khariuchi, is a Nenets from the YNAO and the speaker of the regional parliament, which is the most powerful post in the region after the governor. The president of the world reindeer herders association, Dmitrii Khorolya, a Nenets as well, is also part of the YNAO government.

30. In particular this is public financing from international financial institutions such as the EBRD, but increasingly this is also going to affect financing by private banks. Sakhalin-2 Project lenders also include the Japan Bank for International Co-operation (JBIC), the US Export-Import Bank (USEXIM), and 
the UK Export Credit Guarantee Department (ECGD). Where private banks are lending to projects, many of them are now signing up to the Equator Principles, which offer "a framework to manage environmental and social issues in project financing" and may result in similar levels of international project scrutiny in the future (see Bradshaw 2005a and http://www.equator-principles.com/).

31. The results of public consultation must be submitted for a state ecological expert review (Article 14 of the 1995 law "On the Ecological Expert Review"), while section 4 of the EIA Procedures relates to information dissemination and public participation in the EIA process.

32. Public consultation guidelines were produced by the International Financial Corporation, the private sector arm of the World Bank (http://www .gcgf.org/ifcext/enviro.nsf / AttachmentsByTitle/p_pubconsult/\$FILE/ PublicConsultation.pdf), and EBRD (http://www.ebrd.com/about/policies/ enviro/policy/policy.pdf). These principles have been applied by Sakhalin Energy (http://www.sakhalinenergy.com/en/library.asp; select "Public Consultation and Disclosure Plan" and "Public Grievance Information Leaflet").

33. As for example in the southern YNAO, http://www.sibneft.com/ pages.php?lang $=1 \&$ page $=529$.

34. However, this is not to say that on these deposits ecological problems are all resolved (see Zenko 2001). Encroachment onto pastures is ongoing and problems with old industrial waste cannot be solved by good relations between workers and herders alone.

35. The whole plan is available on the Sakhalin Energy Web site at: http:// www.sakhalinenergy.com/en/documents/doc_lender_soc_4.pdf.

\section{References}

Anderson, D. G. 2000. Identity and Ecology in Arctic Siberia: The Number One Reindeer Brigade. Oxford: Oxford University Press.

2002. "Entitlements, Identity and Time: Addressing Aboriginal Rights and Nature Protection in Siberia's New Resource Colonies." Pp. 99-123 in People and the Land: Pathways to Reform in Post-Soviet Siberia, ed. E. Kasten. Berlin: Dietrich Reimer Verlag.

Arakchaa, K.D. and Zaidfudim P.Kh. 1999. Korennye Malochislennye Narody Severa. Moscow: Nauchnaia Kniga.

Auty, R. 1993. Sustaining Development in Mineral Resource Economies: The Resource Curse Thesis. London: Routledge.

Balzer, Marjorie Mandelstam. 1999. The Tenacity of Ethnicity: A Siberian Saga in Global Perspective. Princeton, NJ: Princeton University Press.

Blommaert, Jan, and Chris Bulcaen. 2000. "Critical Discourse Analysis." Annual Review of Anthropology, 29: 447-466.

Bradshaw, M. J. 2003a. "Sakhalin oblast: Sectoral Globalisation." Pp.141-163 in Russian Regions and Regionalism: Strength through Weakness, ed. G. P. Herd and A. Aldis. London: Routledge Curzon. 
2003b. "Prospects for Oil and Gas Exports to Northeast Asia from Siberia and the Russian Far East, with a Particular Focus on Sakhalin." Sibirica: The Journal of Siberian Studies, 1 (1): 64-86.

—. 2005a. "Environmental Groups Campaign against Sakhalin-2 Project Financing." Pacific Russia Oil and Gas Report. Spring 2005: 3, 14-18.

- 2005b. "The Changing 'Power Geometry' of the Sakhalin Projects." Pacific Russia Oil and Gas Report. Summer 2005: 3, 15-22.

Brooke, J. 2005. "Sakhalin Oil Treasure Is Finally Set to Go." International Herald Tribune, 28 September. http://www.iht.com/articles/2005/09/28/business / sakhalin.php (accessed 28 May 2006).

Chouliaraki, L, and N. Fairclough. 2000. Discourse in Late Modernity: Rethinking Critical Discourse Analysis. Edinburgh: Edinburgh University Press.

Dmitriev, V. S. 2003. “Osobennosti zhizneobespechenia korennogo naselenia Severa v usloviakh promyshlennogo osvoenia i problemy soglasovania interesov." Bulletin Gosudarstvennoi Poliarnoi Akademii, 2: 18-20.

Dobrinskij, L. N., and V. V. Plotnikov. 1997. Ekologiia Khanty-Mansiiskogo Avtonomnogo Okruga. Tyumen.

Einarsson, N., J. N. Larsen, A. Nilsson, and O. R. Young, eds. 2004. Arctic Human Development Report. Akureyri: Stefansson Arctic Institute.

Energy Information Administration. 2006. Russia Country Analysis Brief. http:// www.eia.doe.gov/emeu/cabs/russia.html (accessed 18 July 2006)

Ensminger, J. 2002. "Theory in Economic Anthropology at the Turn of the Century." Pp. ix-xix in Theory in Economic Anthropology, ed. J. Ensminger. Walnut Creek, CA: Altamira Press.

Fairclough, Norman. 1995. Media Discourse. London: Edward Arnold.

Field, L. J., J. A. Fall, T. S. Nighswander, N. Peacock, and U. Varanasi. 1999. Evaluating and Communicating Subsistence Seafood Safety in a Cross-Cultural Context: Lessons Learned from the Exxon Valdez Oil Spill. Pensacola, FL: Society of Environmental Toxicology and Chemistry (SETAC).

Finke, Peter. 2004. Nomaden im Transformationsprozess: Kasachen in der postsozialistischen Mongolei. Münster: LIT.

Follath, E. 2006. "Der Treibstoff des Krieges." Der Spiegel, 13: 76-88.

Fondahl, Gail. 1998. Gaining Ground? Evenkis, Land and Reform in Southeastern Siberia. Boston: Allyn and Bacon.

Fondahl, Gail, and Greg Poelzer. 2003. "Aboriginal Rights in Russia at the Beginning of the Twenty-First Century." Polar Record, 39 (209): 111-122.

Gray, P., and Florian Stammler. 2002. "Siberia Caught Between Collapse and Continuity." Max Planck Research, 3 54-61.

Habeck, Joachim Otto. 2002. "How to Turn a Reindeer Pasture into an Oil Well, and Vice-Versa: Transfer of Land, Compensation and Reclamation in the Komi Republic." Pp. 125-147 in People and the Land: Pathways to Reform in Post-Soviet Siberia, ed. E. Kasten. Berlin: Dietrich Reimer Verlag. . 2005. What It Means to Be a Herdsman: The Practice and Image of Reindeer Husbandry among the Komi of Northern Russia. Münster: LIT Verlag. 
Haller, T., A. Blöchlinger, M. John, E. Marthaler, and S. Ziegler, eds. 2000. Fossile Ressourcen, Erdölkonzerne und indigene Völker. Giessen: Focus.

Hardin, G. 1968. "The Tragedy of the Commons." Science, 162, 3859: 1243-1248. Hausmann, R., and R. Rigobon. 2003. "An Alternative Interpretation of the 'Resource Curse': Theory and Policy Implications." NBER Working Paper Series, Working Paper 9424. http://www.nber.org/papers/w9424.pdf (accessed 18 July 2006)

Hill, F., and C. G. Gaddy. 2003. The Siberian Curse: How Communist Planners Left Russia Out in the Cold, Washington, DC: The Brookings Institution.

Humphrey, Caroline. 1995. "Introduction." Special Issue: Surviving the Transition: Development Concerns in the Post Socialist World. Cambridge Anthropology, 18 (2): 1-12.

Kasten, Erich, ed. 2004. Properties of Culture-Culture as Property. Pathways to Reform in Post-Soviet Siberia. Berlin: Dietrich Reimer Verlag.

Kasten, Erich, ed. 2005. Rebuilding Identities. Pathways to Reform in Post-Soviet Siberia. Berlin: Dietrich Reimer Verlag.

KMAO Department for Information. 2005. Khanty-Mansiiskii Avtonomnyi Okrug Iugra, 75 let. Khanty-Mansiisk.

Kwon, Heonik. 1997. "Movements and Transgressions: Human Landscape in Northeastern Sakhalin." Pp. 143-169 in Arctic Ecology and Identity, ed. S. A. Mousalimas. Budapest: Akademiai Kiado.

Lee, J. 2005. “Squaring Off on Sakhalin: A 'Global' NGO Campaign against Big Oil," Geneva: CASIN. http://www.casin.ch/web/pdf/sakhacastudy.pdf (accessed 18 July 2006)

Karl, T. Lynn. 1997. The Paradox of Plenty: Oil Booms and Petro-States. Berkeley: University of California Press.

Murashko, O. A., ed. 2002. Opyt provedenia etnologicheskoi ekspertizy. Otsenka potentsial'nogo vozdeistviia programmy OAO "Gasprom" poiskovo-razvedochnykh rabot $v$ akvatoriakh Obskoi $i$ Tazovskoi Gub na komponenty ustoichivogo razvitiia etnicheskikh grupp malochislennykh narodov Severa. Radunitsa Publishers, RAIPON.

Murashko, O. A. 2006. "Problemy sosushestvovaniia osobo okhraniaemykh prirodnykh territorii i territorii traditsionnogo prirodopol'zovania v Rossii." Paper presented at the VI Annual Russian and East European Studies conference, VIEPA 2006, Panel 3, Rovaniemi, 30 March.

Najman, B., R. Pomfret, G. Raballand, and P. Sourdin. 2005. "How Are Oil Revenues Redistributed in an Oil Economy? The Case of Kazakhstan." Unpublished Working Paper 2005-18, School of Economics, University of Adelaide.

Neelov, Iurii. 2005. "Perednyi Krai Zemli." Neftegazovaia Vertikal', 12 June. http:// www.ngv.ru/magazin/view.hsql?id=2878\&mid=111 (accessed 16 April 2006).

Newell, Josh. 2004. The Russian Far East: A Reference Guide for Conservation and Development. McKinleyville, CA: Daniel and Daniel.

Novikova, Natalia I. 1997. "Vzaimodejstvie obshchin korennych narodov Severa Rosii i neftedobyvajushchih korporacij. Vzgljad antropologa'." Pp. 
42-62 in Ekologija, obshchestvo i traditsija: Sotsialnye i politicheskie krizisi v SNG v kontekste rasrushenija prirodnoj sredy (Tadschikistan i rossijskij Sever), eds. M. Olkott and A. Malaschenko. Academic Lectures Vol. 15. Moskva: Carnegie Endowment for International Peace.

Novikova, Natalia I. 2000. "Pravo - eto neobkhodimaia forma svobody, ili kljatva na medvezhei lape." Mir Korennykh Narodov / Zhivaia Arktika, 3: 54-58.

Office of the Deputy Prime Minister. 2005. A Practical Guide to the Strategic Environmental Assessment Directive. London: author.

Okoji, M. A. 2002. "Social Implications of the Petroleum Oil Industry in the Niger Delta." International Journal of Environmental Studies, 59 (2): 197-210.

Okotetto, M. N. and B. C. Forbes. 1999. "Conflicts between Yamal-Nenets reindeer husbandry and petroleum development in the forest-tundra and tundra region of Northwest Siberia." In: Kankaanpää, S., Tasanen, T. and Sutinen, M.-L. (eds.). Sustainable development in northern timberline forests. Helsinki: Finnish Forest Research Institute: 95-99.

Oldfield, J. D. 2005. Russian Nature: Exploring the Environmental Consequences of Societal Change. Aldershot: Ashgate Press.

Oldfield, J. D., A. Kouzmina, and D. J. B. Shaw. 2003. "Russia's Involvement in the International Environmental Process: A Research Report." Eurasian Geography and Economics, 44 (2): 157-168.

Olson, M. 1965. The Logic of Collective Action: Public Goods and the Theory of Groups. Cambridge, MA: Harvard University Press.

Ostrom, E. 2000. "Private and Common-Property Rights." Pp. 332-379 in Encyclopedia of Law and Economics, ed. B. Bouckaert and G. De Geest. Cheltenham: Edward Elgar.

- 2002. "The Type of Good and Collective Action." Speech given at the Mancur Olson Memorial Lectures Series, University of Maryland: College Park, 22 February.

Peskov, V. V. 2003. “Otnoshenia Assotsiatsii 'Yasavey's Neftianymi Kompaniami." Pp. 283-291 in Olen' vsegda prav, ed. N. Novikova. Moscow: Strategia Publishers.

Pika, A., and D. Bogoiavlenskii. 1995. "Yamal Peninsula: Oil and Gas Development and Problems of Demography and Health Among Indigenous Populations." Arctic Anthropology, 32 (2): 61-74.

Roon, T. P. 1996. The Uil'ta of Sakhalin. Yuzhno-Sakhalinsk: Sakhalin Regional Publishing House, Sakhalin Regional Museum.

1999. "Promyshlennoe osvoenie i pravovye problemy korennykh narodov Sakhalin (1990-e gody)." Pp.131-136 in Obychnoe pravo i pravovoi pliuralizm [Materials from the 11th International Congress on Customary Law and Legal Pluralism], August 1997, Moscow. Moscow: Nauka.

_. 2002. "Izmeneniia v ekonomike korennykh narodov Sakhalina v XX v." Rasy i narody: sovremennye etnicheskie i rasovye problemy. 28: 146-159.

Round, J. 2005. "Rescaling Russia's geography: the challenges of depopulating the northern periphery." In Europe-Asia Studies. Vol. 57, No. 5, 705-727. 
Rozen, G. 2003. Management Indicators for Assessing the Relations between Oil Companies and Indigenous Peoples. ARPEL Social-Environmental Guideline No. 1. Edmonton, Alberta: Environmental Services Association of Alberta.

Rutledge, I. 2004. “The Sakhalin II PSA: A Production 'Non-Sharing' Agreement, Sheffield: Sheffield Energy and Resources Information Service (SERIS)." http://www.bankwatch.org/documents/sakhalin_psa_11_04_1 .pdf (accessed 28 May 2006).

Sakhalin Environment Watch. 1999. "Konkretnye Predlozheniia." Recommendations on public participation submitted to the seminar "Indigenous people and the environment of the Russian north." 27-28 July, Yuzhno-Sakhalinsk.

Sawyer, S. 2004. Crude Chronicles: Indigenous Politics, Multinational Oil and Neoliberalism in Ecuador. Durham, NC: Duke University Press.

Seifert, T., and K. Werner. 2005. Schwarzbuch Öl. Eine Geschichte von Gier, Krieg, Macht und Geld. Vienna: Zsolnay Verlag.

Secretariat of the Convention on Biological Diversity. 2004. Akwe:Kon Guidelines. Secretariat of the Convention on Biological Diversity.

Ssorin-Chaikov, Nikolai V. 2003. The Social Life of the State in the Siberian Subarctic. Palo Alto, CT: Stanford University Press.

Stammler, Florian. 2003. Überlebensstrategien im postsozialistschen Rußland: Das Beispiel der rentierzüchtenden Khanty und Nenzen in Nordwestsibirien. Cologne: Koelner ethnologische Beitraege.

- 2005a. Reindeer Nomads Meet the Market: Culture, Property and Globalisation at the End of the Land. Münster: LIT Verlag.

—. 2005b. "Sosushchestvovanie Olenevodstva i Neftegazovykh Razrabotok na Yamal'skom Poluostrove." Mir Korennykh Narodov / Zhivaia Arktika, 18: $128-132$.

— 2005c. "The Obshchina Movement in Yamal: Defending Territories to Build Identities?" Pp. 109-134 in Rebuilding Identities: Pathways to Reform in Postsoviet Siberia, ed. E. Kasten. Berlin: Dietrich Reimer Verlag.

Steheli-Pfister, Helen. 1995. Max Müller und das schwarze Gold. [Documentary]. Serie DOK, Swiss TV channel DRS.

Stepanov, V. 1999. Metody etnoekologicheskoi ekspertizy, Moscow: Institute of Ethnology and Anthropology, Russian Academy of Sciences.

Thompson, N. 2004. "Migration and Resettlement in Chukotka: A Research Note," Eurasian Geography E Economics (formerly Post-Soviet Geography), 45, 1:73-81.

Thornton, J., and C. E. Ziegler. 2002. Russia's Far East: A Region at Risk. Seattle, WA: NBR Publications.

Tishkov, V., ed. 2004. Sovremennoe polozhenie i perspektivy ustoichivogo razvitiya korennykh malochislennykh narodov Severa, Sibiri i Dal'nego Vostoka: Nezavisimyi ekspertnyi doklad. Moscow: Nauka.

Tsalik, S. 2002. Caspian Oil Windfalls: Who Will Benefit? New York: Open Society Institute.

Tuisku T. 2002. Nenets Reindeer Herding and Industrial Exploitation in Northwest Russia. Human Organisation, 61 (2): 147-153. 
Vakhtin, N. B., E. V. Golovko, and Peter Shvaittser. 2004. Russkie Starozhily Sibiri: Sotsial'nye i Simvolicheskie Aspekty Samosoznaniia. Moskva: Novoe izd-vo.

Vasin, S. V. 2003. “O nekotorom opyte raboty komiteta Severa Administratsii Surgutskogo Raiona po regulirovania vzaimootnoshenii korennykh malochislennykh narodov s predpriatiami - nedropol'zovateliami." Pp. 292-302 in Olen' vsegda prav, ed. N. Novikova. Moscow: Strategia.

Vatansever, A. 2005. Russia's Growing Dependence on Oil and its Venture into a Stabilization Fund. Energy Security, 28 March. http://www.iags.org/ n0328052.htm (accessed 28 May 2006).

Vitebsky, P. 2005. Reindeer People: Living with Animals and Spirits in Siberia. London: Harper Collins.

Vysokov, M.S., ed. 1995. A History of Sakhalin Oblast. Yuzhno-Sakhalinsk: Sakhalin Centre for the Documentation of Modern History.

Wiget, A., and O. Balalaeva. 1997. "National Communities, Native Land Tenure, and Self-determination among the Eastern Khanty." Polar Geography, 21 (1): 10-33.

Wills, J. 1991. A Place in the Sun: Shetland and Oil. Edinburgh: Mainstream Publishing.

Wilson, Emma. 1999. “Conflict or Compromise? Traditional Natural Resource Use and Oil Exploitation in Northeastern Sakhalin/Noglikskii District." Pp. 69-96 in Economic Development and the Environment on the Sakhalin Offshore Oil and Gas Fields. Sapporo: Hokkaido University. http://src-h.slav .hokudai.ac.jp/sakhalin/eng/71/contents.html (accessed 30 May 2006).

. 2002a. "Est' Zakon, est' i svoi zakony: Legal and Moral Entitlements to the Fish Resources of Nyiski Bay, North-Eastern Sakhalin." Pp. 149-168 in People and the Land: Pathways to Reform in Post-Soviet Siberia, ed. E. Kasten. Berlin: Dietrich Reimer Verlag.

2002b. "Making Space for Local Voices: Local Participation in Natural Resource Management, North-Eastern Sakhalin Island, the Russian Far East." PhD diss., Scott Polar Research Institute, Cambridge University. . 2003. "Freedom and Loss in a Human Landscape: Multinational Oil and Gas Exploitation and the Survival of Reindeer Herding in Northeastern Sakhalin, the Russian Far East." Sibirica, 3 (1): 21-47.

. 2005. "Can Stakeholder Engagement Lead to Sustainable Development Outcomes on Sakhalin?" Paper presented at the ESRC seminar "A Sustainable Future for Sakhalin?" Leicester University, 9 March. http:// www.geog.le.ac.uk/staff/mjb41/ESRCpresentations/emma_wilson.pdf (accessed 30 May 2006).

Yurchak, Alexei. 2005. Everything Was Forever, Until It Was No More: The Last Soviet Generation. Princeton, NJ: Princeton University Press.

Zenko, M. A. 2001. Sovremennyi Yamal: Etnoekologicheskie i etnosotsial'nye problemy. Vol. 139 of Issledovaniia po prikladnoi i neotlozhnoi etnologii. Moscow: Russian Academy of Sciences, Institute of Ethnology and Anthropology. 